\title{
Predictive power of socio-emotional variables on academic performance and chance of dropout
}

Rodolfo Augusto Matteo Ambiel. Universidade São Francisco

Jasiele Aparecida de Oliveira Silva. Faculdade de Ensino e Pesquisa de Itajubá

Acácia Aparecida Angeli dos Santos. Universidade São Francisco

Katya Luciane de Oliveira. Universidade Estadual de Londrina

\begin{abstract}
Socio-cognitive and socio-affective variables are associated with learning and the process of adaptation to higher education. This research aimed to verify, in a longitudinal way, the predictive power of these variables in the academic performance and the chances of dropout perceived by university students. Participants included 136 physical education students from a private institution. A questionnaire on self-efficacy and performance expectations was administered at the beginning of the semester together with the Social and Emotional or Non-cognitive Nationwide Assessment. After knowing the results at the end of the semester, the questionnaire on self-efficacy and satisfaction with performance was administered. The results showed that in a negative sense, the main predictor of the chances of dropout was self-efficacy for conscientiousness. The belief in being organized, self-regulated, and self-motivated leads students to see themselves with lower changes of dropout, regardless of the immediate results of academic assessments.
\end{abstract}

Keywords: psychological evaluation; university; educational evaluation.

\section{Resumo}

Predição das variáveis sociemocionais no desempenho acadêmico e chance de evasão. Variáveis sociocognitivas e socioafetivas estão associadas ao aprendizado e ao processo de adaptação ao ensino superior. Com desenho longitudinal, esta pesquisa objetivou verificar o poder preditivo destas variáveis no desempenho acadêmico e a chance de evasão percebida por estudantes do ensino superior. Participaram 136 alunos de educação física de uma instituição particular. Foram aplicados no início do semestre um questionário sobre autoeficácia e expectativas de desempenho juntamente com o Social and Emotional or Non-cognitive Nationwide Assessment. No final do semestre, após o conhecimento das notas, foi aplicado o questionário sobre autoeficácia e satisfação com o desempenho. Os resultados revelaram que, em sentido negativo, o principal preditor das chances de evasão foi a autoeficácia para conscienciosidade. A crença em ser um aluno organizado, capaz de autorregular-se, ser esforçado e autônomo leva o aluno a perceber-se com menores chances de evasão, independente dos resultados imediatos de avaliações acadêmicas.

Palavras-chave: avaliação psicológica; universidade; avaliação educacional.

\section{Resumen}

Predicción de las variables socioemocionales en el desempeño académico y posibilidad de evasión. Variables sociocognitivas y socioafectivas están asociadas al aprendizaje y al proceso de adaptación a la enseñanza superior. Esta investigación tuvo como objetivo verificar, de forma longitudinal, el poder de predicción de esas variables en el desempeño académico y la posibilidad de evasión percibida por estudiantes de la enseñanza superior. Participaron 136 alumnos de educación física de una institución privada. Fueron aplicados, al comienzo del semestre, un cuestionario sobre autoeficacia y expectativas de desempeño, juntamente con el Social and Emotional or Non-cognitive Nationwide Assessment. Después de conocer las notas al final del semestre, fue aplicado el cuestionario sobre autoeficacia y satisfacción con el desempeño. Los resultados mostraron que, de forma negativa, el principal predictor de las posibilidades de evasión fue la autoeficacia para escrupulosidad. La creencia de ser un alumno organizado, capaz de autorregularse, ser esforzado y autónomo, lleva al alumno a verse con menos posibilidades de evasión, independientemente de los resultados inmediatos de las evaluaciones académicas.

Palabras clave: evaluación psicológica; universidad; evaluación educacional. 
Socio-emotional abilities are variables that can influence academic performance, since it is observed that students present social, emotional, and behavioral difficulties that impact their ability to succeed in academic life (Loos-Sant'Ana \& Trancoso, 2014). For many years, one of the most investigated predictors of school success was intelligence, and, although its importance is recognized, other variables should be considered in this prediction, among which stand out socio-emotional abilities (Cerda et al., 2015).

John and De Fruyt (2015) suggest that the model of the five major personality factors, known in the international literature as the Big Five, functions as an integrative model and organizer of socio-emotional abilities. Along with other collaborators, they developed a largescale assessment tool, based on this model and applied to the school and academic context, called Social and Emotional or Non-cognitive Nationwide Assessment (SENNA) (Primi, Santos, John, \& De Fruyt, 2016). The present study is within this context and it aims to investigate the extent to which these abilities can predict both academic performance and the chances of dropout in higher education.

The relevance of socio-emotional variables to learning has led many authors to examine their impact in the context of education. According to Pérez (2014), socio-emotional variables comprise a group of abilities that facilitate the monitoring of one's emotions in relation to others, as well as one's own feelings. In general, they are recognized as important in the school environment and are associated not only to academic success, but also to success in life, both in children and young adults (Lussier \& Fitzpatrick, 2016).

In a literature review, Ambiel, Pereira and Moreira (2015) verified that in recent years, abilities such as perseverance, collaboration, and responsibility have been proved to be important in students' academic performance and in their daily life outside the university context. The authors believe that the socioemotional variables are more relevant than the cognitive skills, either for the student's individual or collective academic success.

Even in the initial stages of education, results such as those presented by Ana and Trancoso (2014) reveal the association between socio-emotional development and academic performance. The students surveyed had high levels of self-concept and self-esteem, strong control of beliefs in dimensions relevant to academic performance and self-perception of being socially qualified. In the same line, the study by Lizuka, Barrett, Gillies, Cook and Marinovic (2014) conducted with students and professors, verified the existence of a relationship between the benefits of social and emotional learning in academic performance. After conducting an intervention program for six months, the results were promising, not only for the prevention of childhood anxiety, but also to improve the students' self-concept, social skills, and coping skills.

Giunta et al. (2013) emphasize the importance of increasing research on personality traits in studies with other socio-emotional variables. The results of their research with high-school students, resulting from analyses of structural equations showed that conscientiousness, openness, and self-esteem are positively interrelated and that both traits and self-esteem correlate with self-efficacy beliefs. These, in turn, are mediators of the effect of conscientiousness and self-esteem in senior students. The authors also point out that these variables suffer the effect of gender, parental education, and previous school results. In any case, they warn that it is important that teachers be aware of the weight of the students' personality characteristics, so that they can work to increase their beliefs about their own abilities in different areas of the course, regulating their motivation, and using appropriate learning strategies.

Similar findings, also resulting from research with high-school students, were found in Italy by Zuffiano et al. (2013). The authors used hierarchical regression analysis and controlled the effects of variables related to socio-economic level, gender, previous school performance, intelligence, personality traits, and self-esteem. Nonetheless, they established the unique contribution of self-efficacy beliefs to self-regulated learning in the academic performance observed at the end of the course.

Similarly, Diseth, Meland and Breidablik (2014) claim that there is a relation between self-esteem, selfefficacy, and intelligence in students of different formal levels. For the authors, it is also possible to establish prediction between the cited variables and the level of academic performance. Finally, they point to the fact that the components of the self-confidence assessment (self-esteem and self-efficacy) and implicit theories of intelligence are distinct but interrelated factors.

It is possible to assert, therefore, that socio-emotional variables interfere in academic performance, being related to competences and abilities in the execution of academic tasks, assessed in terms of efficiency 
and performance (Galla et al., 2014). However, it should be considered that other conditions, such as the profile of the school (physical and pedagogical environment, didactics, and teacher qualification), family context (parental level of education and participation in school life), and other personal conditions of the students are also relevant variables to explain overall performance (Giunta et al., 2013). On this aspect, Pérez (2014) analyzed strategies and levels of academic engagement of university students in their first year, as well as the relation between these variables and the learning objectives. The results indicated that most students are moderately oriented towards learning objectives, and that they presented achievement goals, with a positive and significant correlation between them.

Many students who are not able to perform well academically fail and end up dropping out of university. In the last ten years, in particular, school failure has been a challenging topic for education researchers, leading Agustiani, Surya and Muwaga (2016) to analyze self-efficacy and self-regulation in university learning. The results of the study revealed that both are associated with academic performance. Therefore, if one of the three variables presents a change, positive or negative, the other variables can also present changes.

Social, emotional, and behavioral problems can impact the student's ability to succeed in university. To predict academic performance, competences such as intelligence, personality traits, and self-esteem can work together, favoring intellectual curiosity, knowledge acquisition, and motivational effort to learn (Lussier \& Fitzpatrick, 2016). Thus, the possibility of an improvement in the academic performance of the university would increase.

In summary, the retrieved studies show the importance of investigating socio-emotional variables, especially self-efficacy, which is characterized by people's beliefs about their ability to exert control over their own life and is an essential and important behavior for success. When people believe that they are capable to act and that their actions will produce the desired results, they are more motivated to act and behave in a way that is more likely to produce the desired result (Bandura, 1977).

In view of the above, the present investigation aimed to verify, under a longitudinal cohort study design, the predictive power of socio-emotional variables in the academic performance and in the chances of dropout perceived by students of higher education. As guiding hypotheses we present: $\mathrm{H} 1$ - The self-reported academic performance in $\mathrm{T} 2$ will be predicted by selfefficacy and performance expectations as well as by the socio-emotional competences of Extraversion and Conscientiousness, assessed in $\mathrm{T} 1$. $\mathrm{H} 2$ - The perceived chances of dropout, evaluated in $\mathrm{T} 2$, will be predicted by the same variable evaluated in $\mathrm{T} 1$, as well as traits of Conscientiousness, also evaluated in T1.

\section{Method}

\section{Participants}

Participants included 136 students enrolled in the Physical Education course, evening program, from a private institution in the state of Minas Gerais, Brazil. Of these, 123 responded to the survey both at time 1 ( $\mathrm{T} 1$ : first stage of collection) and at time 2 (T2: second stage of collection) and were kept in the database. Among these participants, 80 (65\%) were male and 43 (35\%) were female, with ages ranging from 17 to 37 years $(M=21.6 ; S D=3.6)$. Regarding the period of the course, participants were distributed between the first $(n=51)$, third $(n=37)$ and fifth semesters $(n=35)$.

\section{Instruments}

Questionnaire on Self-efficacy and Performance Expectations (QT1): this instrument was developed specifically for this research and administered at stage 1 (T1) of the collection. It surveyed personal aspects such as age, sex, course, semester, institution, and study period. In addition, it contained three questions. In the first one, participants were asked to point out the three disciplines they were enjoying the most until that moment and, for each one, they would point out the grades they would like to obtain in the exams; this variable was called academic performance expectation and, for statistical treatment, it was considered a mean of the three grades mentioned. Then, it was asked how much participants believed they could achieve the mentioned grades and the answer was given on a scale of 1 (I do not believe) to 5 (I totally believe); this variable was called self-efficacy for academic performance. Finally, it was asked about the chance (0 to $100 \%$ ) of dropping out of the current course, a variable called chance of dropout.

Questionnaire on Academic Performance and Satisfaction with Performance (QT2). This instrument was also specifically developed for this study, being administered only in $\mathrm{T} 2$, that is, after the administration of the exams and disclosure of grades. In addition to the identification data, participants were also asked to indicate the three highest grades obtained, as well as the

Estudos de Psicologia, 23(1), janeiro a março de 2018, 14-21 
subjects, variable that was considered as an indicator of academic performance, and a mean from the three grades indicated was also generated. Next, participants were asked to mark, on a scale of 1 to 5 , how satisfied they were with their performances overall. Finally, they were asked again about the chances of dropout.

Social and Emotional or Non-cognitive Nationwide Assessment (SENNA Primi et al., 2016). This instrument, despite its name in English, was fully developed in Portuguese and within Brazilian reality, at the initiative of the Ayrton Senna Institute. The administered version consisted of two sections. The first, composed of 32 items, assessed the socio-emotional competences according to the model of the Big five factors: Extraversion, Agreeableness, Conscientiousness, Openness to new experiences, and Neuroticism. The items were answered on a Likert scale ranging from 1 (nothing to do with me) to 5 (everything to do with me). The second section, composed of 25 items, aimed to evaluate participants' self-efficacy in relation to socio-emotional abilities, i.e., the degree of confidence to perform behaviors related to Extraversion, Conscientiousness, etc. Responses were given on a scale assessing how much people believe they can perform the activities described in the items, ranging from 1 (nothing) to 5 (much).

\section{Proceedings}

This work is part of a larger project, previously approved by a Research Ethics Committee under protocol n. 443.062 and supported by Resolution 466/12 of the National Health Council and complementary resolutions. Prior to collection, a higher education institution in the countryside of the state of Minas Gerais was contacted to request authorization and to clarify the research objectives. Then, the undergraduate students in Physical Education were contacted, to whom the research proposal was explained before the signing of the Free and Informed Consent Form (FICF). The first stage of the collection (T1) occurred at the beginning of the semester, before the first university exams. At the time, the instruments QT1 and SENNA were administered, with an administration time of approximately 50 minutes, always in this sequence. T2 occurred 22 days after T1, when the students had already taken the exams and received the results. At T2 only QT2 was administered, and the mean time was 15 minutes.

\section{Data Analysis}

Statistical analyzes of the data were performed using the IBM SPSS Statistics for Windows ${ }^{\circledR}$ Program,
Version 22.0 (IBM Corp, 2013). Multiple regression analysis was used with stepwise method.

\section{Results}

Initially, statistical tests were performed to justify the use of regressions. Subsequently, we tested the possibility of prediction of the academic performance obtained in the second stage (T2) of the collection, using the multiple regression procedure, with the stepwise method. For this purpose, the variables expectation of academic performance and self-efficacy for academic performance were added in the first block. In the second block, the variables were self-efficacy factors for socio-emotional competences and, in the third block, the five big factors of the socio-emotional competences, with all the independent variables obtained in T1. In the first model, only self-efficacy for academic performance entered as a significant predictor, explaining $10 \%$ of performance variance, and in the second model, self-efficacy for the social-emotional competence of Extraversion was added, increasing the proportion of explained variance to $13 \%$. Therefore, $\mathrm{H} 1$ was partially corroborated. Table 1 shows the coefficients obtained for the models.

Table 1. Predictors of Performance

\begin{tabular}{lcccccc}
\hline \multicolumn{1}{c}{ Model } & \multicolumn{2}{c}{ Non-standardized } & Standardized & $t$ & $p$ \\
\cline { 2 - 4 } & B & $\begin{array}{c}\text { Standard } \\
\text { Error }\end{array}$ & Beta & & \\
\hline & 56.031 & 5.614 & & 9.981 & 0.000 \\
\hline $\begin{array}{l}\text { (Constant) } \\
\text { Self-efficacy for }\end{array}$ & 5.432 & 1.450 & 0.32 & 3.747 & 0.000 \\
$\begin{array}{l}\text { Performance } \\
\text { (Constant) }\end{array}$ & 45.772 & 6.990 & & 6.548 & 0.000 \\
$\begin{array}{l}\text { Self-efficacy for } \\
2\end{array}$ & 5.024 & 1.433 & 0.30 & 3.506 & 0.001 \\
$\begin{array}{l}\text { Performance } \\
\text { Self-efficacy for } \\
\text { Extraversion }\end{array}$ & 3.549 & 1.489 & 0.20 & 2.384 & 0.019 \\
\hline
\end{tabular}

Table 1 demonstrates that in the first model the adjusted beta coefficient of self-efficacy for performance was of 0.32 in relation to academic performance. In the second model, the coefficient of this variable dropped to 0.30 , and that of the self-efficacy for extraversion was of 0.20 .

The second analysis identifies the predictors of the perceived chance of dropout after the exams. For this purpose, a multiple linear regression analysis was performed again, using the stepwise method, inserting as dependent variable the evaluation that the students made, after the tests, about the chance they perceived 
of giving up the course before the end. The predictors were inserted in four blocks: in the first one, the variables self-efficacy for performance, expectation of performance, and evaluation of chance of dropout before the exams (T1); in the second block, the factors of selfefficacy for socio-emotional competences; and in the third, the five factors of socio-emotional competences were inserted. Finally, the fourth block was composed of the variables of academic performance, satisfaction with performance, and difference between expectation and performance, being this variable obtained from the subtraction between performance expectations reported in T1 and self-reported performance in T2.

The best model, with $55 \%$ of variance explained, was composed of the possibility of giving up the course before the end of the first collection, self-efficacy for conscientiousness, and the agreeableness factor. However, it is noteworthy that, the assessment of chance of dropout in T1, alone, explained $52 \%$ of the variance of the same assessment after the exams. Considering the adjusted beta coefficient, the assessment of the chance of dropout in T2 obtained a value of 0.70 , being, therefore, responsible for a large part of the variation in the same assessment, after the exams. This data corroborates part of $\mathrm{H} 2$. However, we decided to run the regression again, maintaining the same general configuration, but excluding the assessment of chance of dropout of $\mathrm{T} 1$ as a predictor.

The new analysis revealed that the best explanatory model for evaluating the chance of dropout after exams was composed of self-efficacy for performance and self-efficacy for conscientiousness, both collected at the first moment. Considering the model only with the first variable, we observed $3 \%$ of applied variance, and when self-efficacy for conscientiousness was included, the proportion increased to $13 \%$. Table 2 shows the results of the models.

Table 2. Predictors of Chance of Dropout

\begin{tabular}{|c|c|c|c|c|c|c|}
\hline & \multirow[t]{2}{*}{ Model } & \multicolumn{2}{|c|}{ Non-standardized } & \multirow{2}{*}{$\begin{array}{c}\text { Standardized } \\
\text { Beta }\end{array}$} & \multirow[t]{2}{*}{$t$} & \multirow[t]{2}{*}{$p$} \\
\hline & & $B$ & $\begin{array}{l}\text { Standard } \\
\text { Error }\end{array}$ & & & \\
\hline \multirow{3}{*}{1} & (Constant) & 1.323 & 0.401 & & 3.302 & 0.001 \\
\hline & $\begin{array}{l}\text { A Self-efficacy for } \\
\text { Performance }\end{array}$ & -0.241 & 0.103 & -0.21 & -2.327 & 0.022 \\
\hline & (Constant) & 2.593 & 0.512 & & 5.068 & 0.000 \\
\hline \multirow[t]{2}{*}{2} & $\begin{array}{l}\text { Self-efficacy for } \\
\text { Performance }\end{array}$ & -0.130 & 0.103 & -0.11 & -1.260 & 0.210 \\
\hline & $\begin{array}{l}\text { Self-efficacy for } \\
\text { Conscientiousness }\end{array}$ & -0.451 & 0.121 & -0.33 & -3.718 & 0.000 \\
\hline
\end{tabular}

Table 2 shows that, in model 1 , the variable selfefficacy for performance, evaluated in T1, was a significant and negative predictor of the chances of dropout in T2. However, in model 2, this independent variable had a significant reduction in its adjusted beta coefficient and was no longer significant, and self-efficacy for Conscientiousness was inserted as a negative and significant predictor of the chances of dropping out after the exams. Thus, self-efficacy for conscientiousness turned out to be the main predictor, and each additional point in this variable in $\mathrm{T} 1$ is related to the decrease of onethird of each point in the assessment of chance of dropout after the exams. Therefore, it can be asserted that $\mathrm{H} 2$ was partially corroborated, since the traits of conscientiousness were expected to be significant predictors for such behaviors, but not self-efficacy.

\section{Discussion and conclusion}

This study had two objectives: to evaluate the predictive power of abilities and other socio-emotional variables regarding academic performance and the perceived chances of dropout in higher education students. Therefore, it can be asserted that the objectives were reached, with hypothesis $1(\mathrm{H} 1)$ partially corroborated and $\mathrm{H} 2$ fully corroborated.

When analyzing the data presented in Table 1 it was possible to observe that each additional point in self-efficacy for performance is positively associated with an increase of approximately one third in the reported grade. On the other hand, a point in self-efficacy for extraversion skills led to a one-fifth increase in the reported grade. The data obtained here are in line with the results obtained in previous studies (Augustiani et al., 2016; Diseth et al., 2014; Zuffiano et al., 2013). Thus, as self-efficacy increases, there is also an improvement in the academic performance of the students in the studied sample.

In conceiving the human personality as a system implying different levels of individual functioning, one can also identify intelligence, personality characteristics, and self-esteem as basic potentials of individuals. However, personal self-efficacy beliefs allow people to transform their basic predispositions into appropriate ones, and these behaviors are conducive to academic success (Giunta et al., 2013). Therefore, as Lussier and Fitzpatrick (2016) point out, social, affective, and cognitive factors may interfere with university performance. 
Specifically regarding self-efficacy for extraversion-related behaviors, John and De Fruyt (2015) report that such a trait is related to the amount of social relationships a person can establish and, in the school context, it concerns to tasks such as asking the teacher or the classmates for help when they are struggling with content, to ask in public when they have any questions, and offering help to colleagues in the classroom or in the academic setting. Thus, the findings of this study suggest that believing in one's ability to perform these activities significantly predicts academic performance (Giunta, et al., 2013).

The data presented in the present study reveal the importance of understanding more about socioaffective variables and their influence on the learning process of university students; understanding that students with both cognitive and affective adjustment difficulties can fail and dropout from the course. Thus, it is necessary to think about appropriate interventions with these students to improve their perception of selfefficacy, their motivation to learn, as well as to improve their academic performance.

Regarding the data reported in Table 2 on the prediction of chances of dropout after the exams results, it was observed that the hypothesis previously designed was only partially corroborated. Interestingly, the results of the exams themselves did not significantly alter the perception of the chances of dropout, since more than $50 \%$ of the variance in T2 was explained by the same variable in T1, which was already expected. Thus, at least in the sample of this study, the chances of dropout perceived by students are more related to other reasons rather than academic performance.

However, the surprising finding of this result is that the main psychological predictor of the chances of dropout was self-efficacy for conscientiousness, in the negative sense. It is surprising since it was expected that this factor's traits would act as predictors, and not the beliefs in one's abilities (John \& De Fruyt, 2015).

The difference between the assessment of beliefs and traits lies in the fact that when people respond to a self-report instrument, they state how much the behaviors reported in the items resemble the behaviors they perform in daily life. On the other hand, when talking about how much one believes in his own capacity for certain performance, we are talking about a conditional, future perspective, although highly predictive of the behaviors themselves (Bandura, 1977).
Therefore, in the findings of the present study, the result points to the protective function that the selfefficacy beliefs for conscientiousness may have regarding perceived chances of dropout. That is, someone who believes that, in the academic context, he (or she) can be organized with his materials and deadlines, can self-regulate his emotions and behaviors, and be dedicated and self-motivated (Primi et al., 2016) tends to perceive lower chances of dropping out, regardless of the immediate results of academic exams.

Despite the interesting results, some limitations in the present study stand out. The first limitation refers to the fact that the sample was selected only in a single course from a single institution, which may have caused bias due to possible specificities. In future studies, there should be larger and more diverse samples in relation to such characteristics. Still in this direction, it will be interesting to observe in future studies the possible variations of these results according to the semester studied, i.e., considering classes of incoming students and students in their final year. In the present study, subsamples per semester were reduced and it was not possible to make such verification. In addition, although the longitudinal design was an interesting proposal, the time between T1 and T2, as well as between evaluations and T2 was relatively short, and it would be interesting to consider evaluations during at least two semesters in further studies.

Finally, we considered only the performance in a single exam as a likely aggravator of the chance of dropout, and it is necessary in the future to explore other reasons that might lead students to consider course withdrawal, such as peer relationships, institutional infrastructure, and lack of family and social support.

It should be clarified that it was not the objective of the present study to establish a direct causal relationship between the studied variables, since the focus was the relation between them. Therefore, the considerations presented here are hypothetical in order to expand the possibilities of future investigations. In addition, long-term studies could verify whether interventions focusing on socio-affective and socio-cognitive variables could positively affect the academic performance of university students.

One aspect that stands out in this research was the lack of public educational policies related to the care of students who have dropped out of college. There are only a few higher education institutions that offer a Student Support Service (SOE). Students who 
present difficulties related to adjustment or academic performance are not given due attention, which makes it impossible to establish interfering factors that may deter them from dropping out of college. Therefore, initiatives that invest in programs of this nature are necessary so that these students do not become statistics in the margin of the educational system.

\section{References}

Agustiani, H., Surya, C., \& Muwaga, M. (2016). Self-efficacy and self-regulated learning as predictors of students academic performance. The Open Psychology Journal, 9, 1-6. doi: 10.2174/1874350101609010001

Ambiel, R. A. M., Pereira, C. P. S., \& Moreira, T. C. (2015). Produção científica em avaliação psicológica no contexto educacional: enfoque nas variáveis socioemocionais. Avaliação Psicológica, 14, 339-346. doi: 10.15689/ap.2015.1403.05

Ana, H. L. S., \& Trancoso, B. S. (2014). Socio-emotional development of brazilian gifted children: Selfbeliefs, social skills, and academic performance. Journal of Latino/Latin American Studies, 6, 54-65. doi: 10.18085/llas.6.1.g438862334102t30

Bandura A. (1977). Self-efficacy: Toward a unifying theory of behavioral change. Psychological Review, 84(2), 191-215. Retrieved from https://www.uky.edu/ eushe2/Bandura/Bandura1977PR.pdf

Cerda, G., Pérez, C, G., C., Navarro, J. I., Aguilar, M., Casas, J. A., \& Aragón, E. (2015). Explanatory model of emotional-cognitive variable in school mathematics performance: A longitudinal study in primary scholl. Frontiers in Psychology, 6, 1-10. doi: 10.3389/ fpsyg.2015.01363

Diseth, A., Meland, E., \& Breidablik, H. J. (2014). Self-beliefs among students: Grade level and gender differences in self-esteem, selfefficacy and implicit theories of intelligence. Learning and Individual Differences, 35, 1-8. doi: 10.1016/j.lindif.2014.06.003

Galla, M. B., Wood, J. J., Tsukayama, E., Har, K., Chiu, W. A., \& Langer, A. D. (2014). A longitudinal multilevel model analysis of the whithin-person and between-person effect of effortful engagement and academic self-efficacy on academic performance. Journal of School Psychology, 52, 295-308. doi: 10.1016/j.jcp.2014.04.001

Giunta, L. D., Alessandri, G., Gerbino, M., Kanacri, P. L., Zuffiano, A., \& Caprata, G. V. (2013). The determinants of scholastic achievement: The contribution of personality traits, self-esteem, and academic self-efficacy. Learning and Individual Differences, 27, 102-108. doi: 10.1016/j.lindif.2013.07.006

John, O. P., \& De Fruyt, F. (2015). Framework for the longitudinal study of social and emotional Sskills in cities. Paris: OECD.

Lizuka, C. A., Barrett, P. M., Gillies, R., Cook, C., R., \& Marinovic, W. (2014). A combined intervention targeting both teachers' and students' social-emotional skills: Preliminary evaluation of students' outcomes. Australian Journal of Guidance and Counselling, 24, 152-166. doi: 10.1017/jgc.2014.12

Loos-Sant'Ana, H., \& Trancoso, B. (2014) Socio-Emotional Development of Brazilian Gifted Children: Self-Beliefs, Social Skills, and Academic Performance. Journal of Latino/Latin American Studies, 6(1), 54-65. doi: 10.18085/llas.6.1.g438862334102t30

Lussier, C. C., \& Fitzpatrick, C. (2016). Feelings of safety at scool, sociemotional functioning, and classroom engagement. Journal of Adolescent Health, 30, 1-8. doi: 10.1016/j. jadohealth.2016.01.003

Pérez, E. E., (2014). Cognitive-motivational variables of beginner university students in the first year of adaptation to the European higher education area. Culture and Education, 26, 417-447. doi: 10.1080/11356405.2014.965446

Primi, R., Santos, D., John, O. P., \& De Fruyt, F. (2016). Development of an inventory assessing social and emotional skills in Brazilian youth. European Journal of Psychological Assessment, 32(1), 5-16. doi: 10.1027/1015-5759/a000343

Zuffiano, A., Alessandri, G., Gerbino, M., Kanacri, B. P. L., Giunta, D. L., Milioni, M., \& Caprara, G. V. (2013). Academic achievement: The unique contribution of self-efficacy beliefs in self-regulated learning beyond intelligence, personality traits, and self-esteem. Learning and Individual Differences, 23, 158-162. doi: 10.1016/j. lindif.2012.07.010 
Rodolfo Augusto Matteo Ambiel, Doutor em Psicologia pela Universidade São Francisco (USF), é Professor assistente no

Programa de Pós-Graduação Stricto Sensu em Psicologia, Universidade São Francisco (USF). Endereço para correspondência: Rua Waldemar César da Silveira, 105 Vl. Cura D'Ars (SWIFT), Campinas - São Paulo CEP 13045-510. Telefone: (19) 37793371.

E-mail: ambielram@gmail.com

Jasiele Aparecida de Oliveira Silva, Mestre em Educação pela Universidade do Vale do Sapucaí (UNIVAS), é Professora na Faculdade de Ensino e Pesquisa de Itajubá (FEPI). E-mail: jasiele_oliveira@yahoo.com.br

Acácia Aparecida Angeli dos Santos, Doutora em Psicologia Escolar e do Desenvolvimento Humano pela Universidade de São Paulo (USP), é Professora Titular da Universidade São Francisco (USF).

E-mail: acacia.santos@usf.edu.br

Katya Luciane de Oliveira, Doutora em Psicologia, Desenvolvimento Humano e Educação pela Faculdade de Educação da Universidade de Campinas (Unicamp), Estágio Pós-doutoral no Programa de Pósgraduação Stricto Sensu da Universidade São Francisco (USF), é Professora Associada da Universidade Estadual de Londrina (UEL).

E-mail: katyauel@gmail.com

Received in Jun.13.17

Revised in Apr.02.18

Accepted in Apr.20.18 